\title{
Uji Toksisitas Ekstrak Daun Nicolaia atropurpurea Val. Terhadap Serangga Hama Spodotera litura Fabricus (Lepidoptera: Noctuidae)
}

\section{Toxicity Assay of Nicolia atropurpurea Leaf Extract against Armyworm Spodoptera litura}

\author{
Asmaliyah $^{1}$, Sumardi ${ }^{2}$, dan/and Musyafa $^{2}$ \\ ${ }^{1}$ Balai Penelitian Kehutanan Palembang \\ Jl. Kol. H. Burlian KM. 6,5 Kotak Pos 179, Puntikayu, Palembang \\ Telp./Fax. (0711) 414864 \\ ${ }^{2}$ Fakultas Kehutanan, Universitas Gadjah Mada \\ Jl. Agro, Bulaksumur 55281, Yogyakarta
}

Naskah masuk : ; Naskah diterima :

\begin{abstract}
Nicolaia atropurpurea (Zingiberaceae) has commonly been used by local people as botanical insecticides to protect agricultural crops and forest plantation from insect. However, its scientific basis have not been yet available. This research was done to fill the gap. Two experiments were done in this study: Experiment 1, study on the effect of extraction method and solvent used for extraction on toxicity of N. atropurpurea leaf extract were carried out using direct contact methods. A completely randomized design with 3 replications.. Treatments consisted of six of concentration level. Experiment 2 , study on toxicity $\left(L C_{50}\right.$ and $L C_{95}$ value) of ethyl acetate of $N$. atropurpurea leaf extract were carried out using direct contact method. A completely randomized design with 3 replications. Treatment consisted of concentrations level six. The Results showed that $N$. atropurpurea leaf extract was toxic to the larvae of S.litura when it applied with direct contact method. Ethyl acetate extract produced by soaking method show the highest toxicity, with $L C_{50}$ and $L C_{95}$ values of $0,18 \%$ and $0,54 \%$, respectively.
\end{abstract}

\section{Keywords: toxicity, Nicolaia atropurpurea leaf extract, Armyworm Spodoptera litura}

\begin{abstract}
ABSTRAK
Nicolaia atropurpurea (Zingiberaceae) secara tradisional telah digunakan oleh masyarakat lokal untuk melindungi tanaman budidaya dan hutan tanaman dari serangan hama. Namun penggaliannya secara ilmiah terhadap potensinya sebagai sumber insektisida nabati belum pernah diteliti, sehingga sejauh mana toksisitas ekstrak daun $N$. atropurpurea ini belum diketahui secara pasti. Oleh karena itu, penelitian ini dilakukan untuk tujuan tersebut. Penelitian ini dilakukan dalam 2 tahapan percobaan, yaitu: Percobaan 1 , pengujian cara ekstraksi dan jenis pelarut yang digunakan terhadap toksisitas ekstrak daun $N$. atropurpurea dengan metode kontak. Percobaan menggunakan Rancangan Acak Lengkap (RAL) dengan 3 ulangan. Perlakuan terdiri dari 6 taraf konsentrasi. Percobaan 2, pengujian toksisitas (nilai $\mathrm{LC}_{50}$ dan $\mathrm{LC}_{95}$ ) ekstrak etil asetat daun $N$. atropurpurea dengan metode kontak. Percobaan menggunakan RAL dengan 3 ulangan. Perlakuan terdiri dari 6 taraf konsentrasi. Hasil penelitian menunjukkan bahwa ekstrak daun $N$. atropurpurea yang diaplikasikan dengan metode kontak bersifat toksik terhadap larva Spodoptera litura instar ketiga. Ekstrak yang paling toksik dihasilkan dari ekstraksi maserasi bertingkat dengan menggunakan pelarut etil asetat dengan nilai $\mathrm{LC}_{50}$ dan $\mathrm{LC}_{95}$ sebesar $0,18 \%$ dan $0,54 \%$.
\end{abstract}

\section{Kata kunci : Toksisitas, ekstrak daun Nicolaia atropurpurea, Spodoptera litura}

\section{PENDAHULUAN}

Seiring dengan semakin kompleknya permasalahan hama pada hutan tanaman, maka alternatif yang lebih bijaksana dan memuaskan untuk mengatasi permasalahan tersebut adalah dengan menerapkan konsep Pengendalian Hama Terpadu (PHT). Taktik-taktik dalam PHT meliputi penggunaan agen atau produk pengendali hayati, penggunaan tanaman resisten, penggunaan insektisida sintetik yang bersifat spesifik dan luas spektrumnya sempit (Sumardi, 2007). PHT juga 
mendukung penelitian dan pemanfaatan senyawa aktif alami yang berasal dari tanaman yang dapat digunakan untuk mengatasi permasalahan hama pada hutan tanaman (Hiljie dan Mora, 2006).

Salah satu kelompok tumbuhan yang potensial dikembangkan sebagai sumber insektisida nabati baru adalah zingiberaceae (Dadang, 1999; Yang et al., 2004). Hasil-hasil penelitian sebelumnya membuktikan bahwa ekstrak dan atau senyawa aktif dari berbagai species zingiberaceae memiliki aktivitas insektisida, repelen dan antifeedant. Jenis-jenis tanaman zingiberaceae yang dilaporkan mempunyai aktivitas terhadap serangga hama, antara lain tepung rizom kering Curcuma longa bersifat menghalangi serangan serangga hama gudang Tribolium castaneum (Nugroho et al., 1996). Ekstrak rimpang $C$. xanthorriza, $C$. zedoaria, Kaempferia galanga dan K. pandurata bersifat insektisida terhadap larva Spodoptera littoralis yang diaplikasikan melalui integumen larva (Pandji et al., 1993). Tawata et al. (1996) juga menginformasikan bahwa daun dari genus Alpinia mempunyai aktivitas insektisida terhadap rayap. Esktrak biji Aframomum melequeta mempunyai aktivitas kuat sebagai penghambat makan rayap Reticulitermes speratus (Escoubas et al., 2000).

Didasari hal ini, maka penggalian potensi spesies tanaman yang berasal dari famili zingiberaceae sebagai sumber insektisida nabati baru cukup tepat dan masih terbuka lebar. Nicolaia atropurpurea Val. yang dikenal dengan nama kecombrang, atau honje merupakan salah satu jenis tumbuhan hutan dari famili zingiberaceae yang potensial untuk dikembangkan sebagai sumber insektisida nabati baru. Di beberapa daerah di kepulauan Sumatera, spesies ini merupakan salah satu tumbuhan yang secara tradisional dimanfaatkan masyarakat lokal untuk melindungi tanaman budidaya dari serangan organisme pengganggu.

Kandungan komponen kimia yang terdapat dalam daun, batang, bunga dan rizom hampir semua genus dari famili zingiberaceae, termasuk genus Nicolaia terdiri dari flavonoid, saponin, polifenol, minyak atsiri, alkaloid, steroid dan triterpenoid (Tampubolon et al., 1983; Naufalin, 2005; Jaafar et al., 2007; Departemen Kesehatan, 2008). Hasil-hasil penelitian sebelumnya menunjukkan flavonoid, polifenol, alkaloid, minyak atsiri, saponin berfungsi sebagai racun serangga, penolak makan, mempengaruhi hormone serangga, mengganggu fungsi-fungsi organ tubuh dan sebagai insektisida (Harborne, 1987; Robinson, 1995; Kardinan, 2005; Doke, 2006). Namun sampai sekarang penggalian terhadap potensi spesies $N$. atropurpurea sebagai sumber insektisida nabati belum pernah diteliti, sehingga sejauh mana toksisitas ekstrak daun $N$. atropurpurea ini belum diketahui secara pasti.

Pemilihan pelarut organik yang digunakan dalam mengekstrak komponen bioaktif dan cara ekstraksinya merupakan faktor penentu untuk pencapaian tujuan dan sasaran ekstraksi komponen. Mendapatkan ekstrak yang baik dilakukan ekstraksi secara bertingkat dimulai dengan pelarut non polar, lalu dengan pelarut semi polar dan polar sehingga diperoleh ekstrak yang mengandung berturut-turut senyawa non polar, semi polar dan polar.

Berdasarkan keterangan di atas, maka penelitian ini dilakukan untuk mengetahui toksisitas ekstrak daun $N$. atropurpurea dan pengaruh cara ekstraksi serta jenis pelarut yang digunakan terhadap toksisitas ekstrak daun $N$. atropurpurea. Penelitian ini menggunakan serangga hama Spodoptera litura karena spesies ini sebagai bioindikator untuk pengujian insektisida baru (Schneider et al., 2000).

\section{METODOLOGI}

\section{A. Perbanyakan Serangga Uji}

Ulat atau larva S. litura diperoleh dari hasil perbanyakan di Laboratorium Fisiologi, Jurusan Proteksi Tanaman Fakultas Pertanian IPB. Selama pemeliharaan ulat diberi makan daun keladi dan sebagai tempat pemeliharaan digunakan wadah plastik berventilasi yang beralaskan kertas saring. Menjelang berkepompong ulat diletakkan dalam wadah plastik lainnya yang berisi serbuk gergaji steril setebal $10 \mathrm{~cm}$ sebagai tempat berkepompong sampai muncul serangga dewasa (ngengat). Ngengat yang terbentuk kemudian dipindahkan ke dalam stoples besar yang bagian atasnya ditutupi dengan kain kasa dan di sekeliling toples ditutupi dengan kertas tisu. Di dalam stoples diletakkan daun keladi segar sebagai tempat peletakan telur dan dimasukkan juga cairan madu yang telah diencerkan dan diserapkan pada kapas sebagai pakan ngengat. Kelompok telur yang diletakkan, dikumpulkan setiap hari dan dipindahkan ke dalam wadah plastik sampai menjadi larva. Perkembangan larva diikuti setiap hari dan sebagian larva yang siap ganti kulit 
menjadi instar ke tiga ditempatkan dalam wadah plastik terpisah dari larva-larva lain. Larva instar ke tiga generasi ke dua lebih kurang 8 jam setelah ganti kulit digunakan untuk pengujian.

\section{B. Persiapan Materi Tanaman dan Ekstrak}

Materi tanaman dikumpulkan dari lokasi Taman Nasional Bukit Barisan Selatan (TNBBS) yang terletak di Pekon Kubu Perahu, Kec. Balik Bukit, Kab. Lampung Barat, Prov. Lampung. Daun $N$. atropurpurea yang diperoleh dari lapangan dikering udarakan kemudian dipotongpotong dan selanjutnya dihaluskan hingga menjadi serbuk. Serbuk halus kemudian dimasukkan ke dalam botol dan dimaserasi dengan menggunakan berbagai pelarut organik yang berbeda kepolarannya, yaitu n.heksan (nonpolar), etil asetat (semi polar) dan metanol (polar).

Ekstrak yang dihasilkan diperoleh dengan dua cara, yaitu ekstraksi cair-cair (partisi) dan ekstraksi maserasi bertingkat (perendaman). Ekstraksi cair-cair, diawali dengan merendam serbuk daun dengan pelarut metanol selama minimal 24 jam dalam botol, kemudian disaring dengan corong kaca yang dialasi dengan kertas saring. Ampas serbuk daun kemudian dimaserasi ulang dengan metanol sampai ekstrak jernih (minimal 3 kali pengulangan). Cairan ekstrak hasil saringan atau filtrat kemudian dimasukkan ke dalam labu penguap, yang terlebih dahulu ditimbang, untuk menguapkan pelarutnya dengan menggunakan rotary evaporator pada suhu $50^{\circ}-60^{\circ} \mathrm{C}$ dan tekanan rendah $(500-700$ $\mathrm{mmHg}$ vakum). Setelah penguapan selesai, labu berisi ekstrak ditimbang lagi, dan selisih antara hasil kedua penimbangan tersebut merupakan bobot ekstrak (\%). Ekstrak kasar metanol kemudian dipartisikan dengan menggunakan corong pemisah dalam campuran pelarut metanol dan n-heksan, kemudian dilanjutkan dengan pelarut etil asetat. Masing-masing fase yang dihasilkan selanjutnya diuapkan pelarutnya dengan rotary evaporator. Esktrak yang dihasilkan disebut ekstrak n-heksan, ekstrak etil asetat dan ekstrak metanol, yang kemudian disimpan dalam lemari es $\left(\leq 4^{\circ} \mathrm{C}\right)$ hingga saat digunakan.

Ekstrak maserasi bertingkat diawali dengan perendaman menggunakan pelarut nheksan, kemudian etil asetat dan terakhir metanol. Campuran bubuk daun dan pelarut tersebut dimaserasi atau direndam selama minimal 24 jam. Ekstrak kemudian disaring sampai jernih dengan menggunakan corong kaca yang dialasi kertas saring lokal. Filtrat yang dihasilkan kemudian dimasukkan ke dalam labu penguap, yang telah ditimbang, untuk menguapkan pelarutnya dengan menggunakan rotary evaporator pada suhu $50^{\circ}-60^{\circ} \mathrm{C}$ dan tekanan rendah (500-700 mmHg vakum). Setelah penguapan selesai, labu berisi ekstrak ditimbang lagi, selisih antara hasil kedua penimbangan tersebut merupakan bobot ekstrak (\%). Esktrak yang dihasilkan disebut ekstrak n-heksan, ekstrak etil asetat dan ekstrak metanol, yang kemudian disimpan dalam lemari es $\left(\leq 4^{\circ} \mathrm{C}\right)$ hingga saat digunakan.

\section{Bioassay atau Uji Hayati}

\section{Percobaan 1: Pengujian Pengaruh Cara Ekstraksi dan Pelarut yang Digunakan terhadap Toksisitas Ekstrak Daun N. atropurpurea}

\subsection{Uji toksisitas ekstrak daun $N$.} atropurpurea hasil ekstraksi cair-cair

Pengujian ini menggunakan 2 jenis ekstrak, yaitu ekstrak metanol dan ekstrak nheksan yang diperoleh dari ekstraksi cair-cair, sedangkan ekstrak etil asetat tidak dilakukan pengujian karena rendemen yang dihasilkan tidak mencukupi untuk pengujian. Perlakuan untuk masing-masing ekstrak menggunakan enam taraf konsentrasi, yaitu $5,00 \%, 2,50 \%$, $1,25 \%, 0,63 \%, 0,31 \%$ dan $0 \%$ (kontrol/tanpa ekstrak). Pada setiap taraf konsentrasi dan kontrol diulang tiga kali dan pada setiap ulangan digunakan 10 ekor larva $S$. litura instar ketiga. Jadi setiap kelompok terdapat 30 ekor larva.

Sebelum membuat larutan uji terlebih dahulu membuat larutan induk dengan konsentrasi $5 \%$, dengan cara sebanyak 5 gram ekstrak dilarutkan dalam campuran deterjen dan aceton dengan konsentrasi masing-masing 0,2\% dan $1 \%$. Campuran ekstrak dengan deterjen dan aceton dimasukkan dalam gelas ukur, kemudian ditambahkan air hingga mencapai tera $100 \mathrm{ml}$. Larutan induk kemudian diambil 25, 12,5, 6,25 dan 3,12 $\mathrm{ml}$ dimasukkan ke dalam gelas ukur sehingga konsentrasi menjadi $2,50 \%, 1,25 \%$, $0,63 \%$ dan $0,31 \%$ setelah ditambahkan air hingga $50 \mathrm{ml}$. Pada perlakuan kontrol hanya menggunakan campuran air dengan pengemulsi deterjen dan aceton tanpa ekstrak, dengan konsentrasi masing-masing $0,2 \%$ dan $1 \%$. Pengujian dilakukan dengan metode kontak.

\section{Cara Kerja}

Serangga uji (larva $S$. litura instar ke tiga) sebanyak 10 ekor dimasukkan ke dalam kurungan kasa kawat pencelup dan kemudian 
dicelupkan dalam sediaan ekstrak uji dengan konsentrasi tertentu pada setiap pelarut selama 10 detik sebanyak 3 kali pengulangan untuk setiap perlakuan. Serangga kontrol dicelup dalam air pengencer (campuran pengemulsi dengan aceton). Kurungan pencelup kemudian ditiriskan di atas tisu sekitar 1 menit, kemudian serangga uji dipindahkan dalam wadah plastik berdiameter $5,5 \mathrm{~cm}$ satu per satu, kemudian dalam wadah plastik yang sudah terdapat serangga uji tersebut diletakkan pakan daun keladi berbentuk bujur sangkar $(3 \times 3 \mathrm{~cm})$. Larva diganti pakannya setiap hari dengan yang segar hingga mencapai stadia pupa. Jumlah larva yang mati dicatat setiap hari hingga hari ke tujuh setelah perlakuan. Data jumlah larva yang mati (mortalitas) kemudian dianalisis dengan analisis probit (Finney, 1971) dengan program komputer SPSS version 13.

\subsection{Uji toksisitas ekstrak daun $N$. atropurpurea hasil ekstraksi maserasi bertingkat}

Pengujian ini menggunakan 3 jenis ekstrak, yaitu ekstrak n-heksan, ekstrak metanol dan ekstrak etil asetat yang dihasilkan dari ekstraksi maserasi bertingkat. Pada masing-masing ekstrak menggunakan perlakuan enam taraf konsentrasi, yaitu $5,00 \%, 2,50 \%, 1,25 \%, 0,63 \%$, $0,31 \%$ dan kontrol (tanpa ekstrak). Pada setiap taraf konsentrasi dan kontrol diulang tiga kali dengan menggunakan 30 ekor larva instar ketiga.

Pembuatan larutan uji, sama seperti pada percobaan 1.1. Pada perlakuan kontrol hanya menggunakan campuran air dengan pengemulsi deterjen dan aceton tanpa ekstrak, dengan konsentrasi masing-masing $0,2 \%$ dan $1 \%$. Pengujian ini dilakukan dengan metode kontak (metode celup serangga uji) sama seperti pada percobaan 1.1. Pengamatan dilakukan setiap hari terhadap jumlah larva yang mati selama tujuh hari. Data jumlah larva yang mati (mortalitas) diolah dengan analisis probit (Finney, 1971) dengan program komputer SPSS version 13 untuk menentukan kisaran konsentrasi yang akan digunakan pada uji penentuan $\mathrm{LC}_{50}$ dan $\mathrm{LC}_{95}$ pada uji sebenarnya.

\section{Percobaan 2. Pengujian Toksisitas Ekstrak Daun N. atropurpurea terhadap Serangga Uji S. litura}

Percobaan ini dilakukan untuk menentukan nilai $\mathrm{LC}_{50}$ dan $\mathrm{LC}_{95}$. Ekstrak yang terbukti memiliki aktivitas insektisida paling tinggi (toksisitas paling tinggi) pada uji pendahuluan diuji lanjut dengan menggunakan lima taraf konsentrasi yang ditentukan berdasarkan hasil uji pendahuluan. Penentuan konsentrasi dilakukan sesuai prosedur yang diuraikan oleh Prijono (2003). Konsentrasi yang digunakan adalah yang diperkirakan dapat mematikan larva $15-95 \%$ dan kontrol. Setiap taraf konsentrasi dan kontrol diulang sebanyak tiga kali dengan menggunakan 90 ekor larva instar ke tiga per perlakuan.

Metode pengujian dilakukan dengan metode kontak sama dengan pengujian sebelumnya, yang berbeda adalah jumlah serangga uji dan tingkat konsentrasi ekstrak. Pengamatan mortalitas larva uji dilakukan setiap hari hingga hari ke lima setelah perlakuan. Bila mortalitas larva uji kontrol lebih besar dari $20 \%$, pengujian di atas harus diulangi. Data mortalitas larva dalam persentase yang berkisar antara 0$100 \%$ akan ditransformasi ke Arcsin $\sqrt{ } \%$ sebelum diolah dengan analisis varians pada taraf $5 \%$ dengan menggunakan program SAS (SAS Institute, 1997). Perbandingan nilai tengah antar perlakuan dilakukan dengan uji selang berganda Duncan. Hubungan antara konsentrasi ekstrak dengan mortalitas serangga uji diolah dengan analisis korelasi. Penentuan nilai $\mathrm{LC}_{50}$ dan $\mathrm{LC}_{95}$ dilakukan dengan analisis probit dengan program SPSS Version. 13.

Tabel (Table) 1. Bobot ekstrak dan rendemen hasil ekstraksi dengan cara ekstraksi cair- cair dan ekstraksi maserasi bertingkat (weight and content of extract by partition and soaking method)

\begin{tabular}{|l|c|c|}
\hline Cara ekstraksi (Extraction method $)$ & Bobot ekstrak (Extract weight) $(\mathrm{g})$ & Rendemen $($ content $)(\%)$ \\
\hline Ekstraksi cair-cair $(200 \mathrm{~g})(1: 10)$ & & \\
- Ekstrak n-heksan & 4,70 & 2,35 \\
- Ekstrak etil asetat & 0,24 & 0,12 \\
- Ekstrak metanol & 12,94 & 6,47 \\
\hline Ekstraksi maserasi bertingkat & & \\
(2000 g) (1:5) & 19,00 & 0,95 \\
- Ekstrak n-heksan & 26,40 & 1,32 \\
- Ekstrak etil asetat & 29,54 & 1,48 \\
- Ekstrak metanol & \multicolumn{2}{|l}{} \\
\hline
\end{tabular}




\section{HASIL DAN PEMBAHASAN}

\section{A. Hasil Pengamatan}

\section{Cara Ekstraksi terhadap Bobot dan Rendemen Ekstrak}

Bobot ekstrak dan rendemen hasil ekstrak yang diperoleh dengan cara ekstraksi cair-cair dan ekstrak maserasi bertingkat menunjukkan rendemen hasil ekstraksi cair-cair lebih tinggi dari pada ekstrak yang diperoleh dengan cara maserasi bertingkat. Ekstraksi dengan menggunakan pelarut metanol paling tinggi rendemennya dibandingkan dengan menggunakan pelarut etil asetat dan n-heksan baik pada ekstraksi cair-cair maupun ekstraksi maserasi bertingkat (Tabel 1).

\section{Uji Toksisitas Ekstrak Daun $N$. atropurpurea Hasil Ekstraksi Cair-cair}

Hasil pengujian terhadap masing-masing ekstrak yang dihasilkan dengan cara ekstraksi cair-cair terhadap mortalitas larva $S$. litura pada hari ke tujuh setelah perlakuan dapat dilihat pada Tabel 2. Hasil pengujian menunjukkan bahwa, pada perlakuan ekstrak metanol daun $N$. atropurpurea kematian sudah terjadi satu hari setelah perlakuan (24 jam). Pada semua rentang konsentrasi yang diuji, mortalitas larva pada hari pertama setelah perlakuan sudah cukup banyak dan relatif konstan pada hari berikutnya hingga hari ke tujuh setelah perlakuan. Namun, perlakuan ekstrak metanol ini masih kurang efektif dalam menyebabkan kematian larva $S$. litura instar ketiga. Hal ini disebabkan pada konsentrasi yang paling tinggi yaitu pada konsentrasi $5,00 \%$ hanya dapat mematikan 18 dari 30 ekor larva uji atau 60,00\% (Gambar 1). Deptan (1995), menyatakan insektisida dianggap efektif bila mampu membunuh serangga uji minimal $80 \%$.

Hasil pengujian terhadap ekstrak n-heksan daun $N$. atropurpurea juga masih kurang efektif dalam menyebabkan kematian larva $S$. litura. Kematian pada konsentrasi tertinggi yaitu 5,00\% baru dapat mencapai kematian 23 ekor dari 30 larva uji atau $76,67 \% 24$ jam setelah perlakuan. Pola perkembangan mortalitas larva sama dengan pola perkembangan mortalitas ekstrak metanol yaitu mortalitas larva sudah cukup banyak pada hari pertama setelah perlakuan dan relatif konstan pada hari berikutnya hingga hari ke tujuh setelah perlakuan (Gambar 2). Oleh karena itu kedua ekstrak hasil ekstraksi cair-cair ini tidak dilakukan analisis probit.

Tabel(Table) 2. Mortalitas larva uji pada masing-masing ekstrak daun N. atropurpurea setelah 24 jam (Mortality of larvae on N. atropurpurea leaf extract after 24 hour)

\begin{tabular}{|c|c|c|c|c|c|}
\hline \multirow{2}{*}{$\begin{array}{c}\text { Metode } \\
\text { ekstraksi } \\
\text { (Extraction) }\end{array}$} & \multirow{2}{*}{$\begin{array}{c}\text { Konsentrasi } \\
\text { (Concentration) } \\
(\%)\end{array}$} & \multirow{2}{*}{$\begin{array}{c}\text { Jumlah } \\
\text { larva } \\
\text { (Number of } \\
\text { larvae) }\end{array}$} & \multicolumn{3}{|c|}{ Mortalitas (Mortality) (\%) } \\
\hline & & & $\begin{array}{c}\text { Ekstrak } \\
\text { n-heksan }\end{array}$ & $\begin{array}{c}\text { Ekstrak } \\
\text { etil asetat }\end{array}$ & $\begin{array}{l}\text { Ekstrak } \\
\text { metanol }\end{array}$ \\
\hline \multirow{6}{*}{$\begin{array}{l}\text { Ekstraksi } \\
\text { Cair-cair }\end{array}$} & 5,00 & 30 & 76,67 & - & 60,00 \\
\hline & 2,50 & 30 & 66,67 & - & 33,33 \\
\hline & 1,25 & 30 & 53,33 & - & 53,33 \\
\hline & 0,63 & 30 & 43,31 & - & 43,33 \\
\hline & 0,31 & 30 & 23,33 & - & 43,33 \\
\hline & Kontrol & 30 & 0 & - & 0 \\
\hline \multirow{6}{*}{$\begin{array}{l}\text { Ekstraksi } \\
\text { Maserasi } \\
\text { Bertingkat }\end{array}$} & 5,00 & 30 & 90,00 & 100,00 & 100,00 \\
\hline & 2,50 & 30 & 86,67 & 100,00 & 100,00 \\
\hline & 1,25 & 30 & 70,00 & 100,00 & 90,00 \\
\hline & 0,63 & 30 & 60,00 & 90,00 & 83,33 \\
\hline & 0,31 & 30 & 46,67 & 86,67 & 63,33 \\
\hline & Kontrol & 30 & 3,33 & 3,33 & 3,33 \\
\hline
\end{tabular}




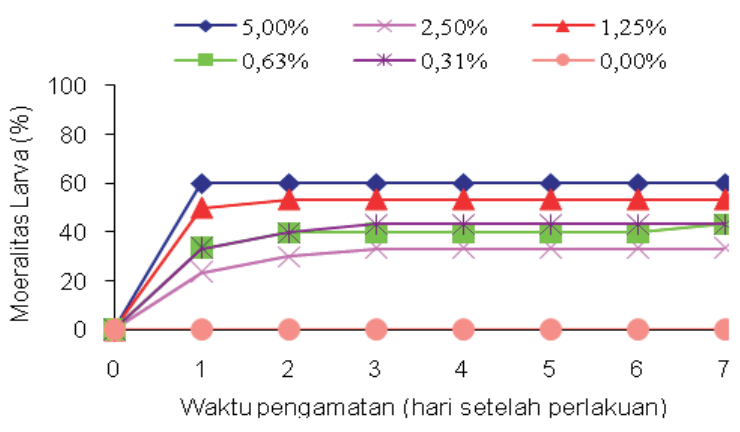

Gambar(Figure) 1. Mortalitas larva S. litura setelah perlakuan pada ekstrak metanol (ekstraksi cair-cair) dengan metode kontak (Mortality of larvae on methanol extract by partition extraction with direct contactmethod)

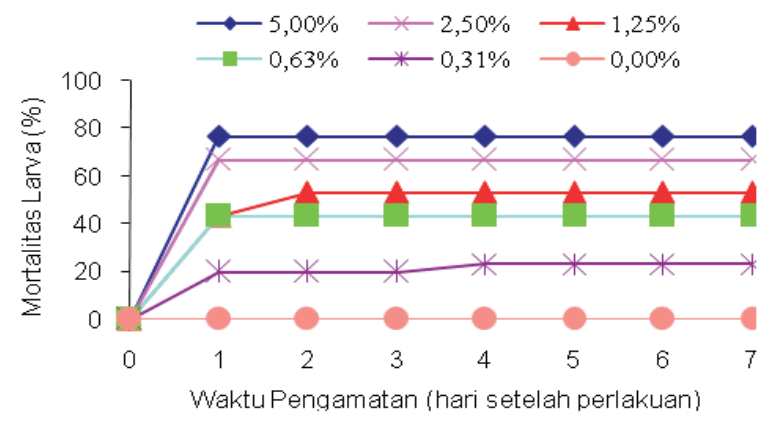

Gambar(Figure) 2. Mortalitas larva S. litura setelah perlakuan pada ekstrak n-heksan (ekstraksi cair-cair) dengan metode kontak (Mortality of larvae on n-hexan extract by partition extraction with direct contactmethod)

\section{Uji Toksisitas Ekstrak Daun $N$. atropurpurea Hasil Ekstraksi Maserasi Bertingkat}

Hasil pengujian masing-masing ekstrak daun $N$. atropurpurea terhadap mortalitas larva $S$. litura pada hari ke tujuh setelah perlakuan dapat dilihat pada Tabel 2. Hasil pengujian ini menunjukkan senyawa kimia ekstrak daun $N$. atropurpurea memiliki daya bunuh atau bersifat toksik terhadap larva $S$. litura. Toksisitasnya sangat kuat hanya bila diaplikasikan secara kontak. Pada masing-masing ekstrak daun $N$. atropurpurea, menunjukkan pola perkembangan mortalitas $S$. litura yang sama pada semua rentang konsentrasi uji, yaitu kematian larva sudah terlihat nyata pada hari pertama (24 jam) setelah perlakuan dan relatif konstan pada hari berikutnya hingga hari ke tujuh setelah perlakuan (Gambar 3, 4 dan 5).

Hasil pengujian ini menunjukkan, ekstrak etil asetat dapat mematikan larva sebesar $100 \%$ paling cepat dibandingkan ekstrak metanol dan ekstrak n-heksan 1 hari (24 jam) setelah perlakuan karena pada konsentrasi 1,25\% sudah dapat mematikan larva sebesar 100\%. Waktu kematian ekstrak etil asetat juga lebih cepat, pada konsentrasi $1,25 \%, 2,50 \%$ dan $5,00 \%$ dapat menyebabkan kematian sebesar $100 \%$ hanya satu hari setelah perlakuan. Sedangkan ekstrak metanol pada konsentrasi $2,50 \%$ baru dapat menyebabkan kematian sebesar $100 \%$ pada hari ke empat setelah perlakuan dan esktrak n-heksan pada konsentrasi $5,00 \%$ juga baru dapat menyebabkan kematian sebesar $90 \%$ pada hari ke empat setelah perlakuan.

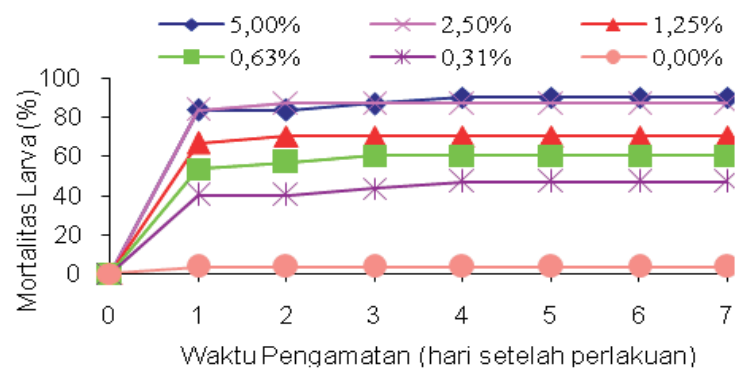

Gambar(Figure)3. Mortalitas larva S. litura setelah perlakuan pada ekstrak n-heksan (esktraksi maserasi bertingkat) dengan metode kontak (Mortality of larvae on $n$-hexan extract by soaking extraction with direct contact method)

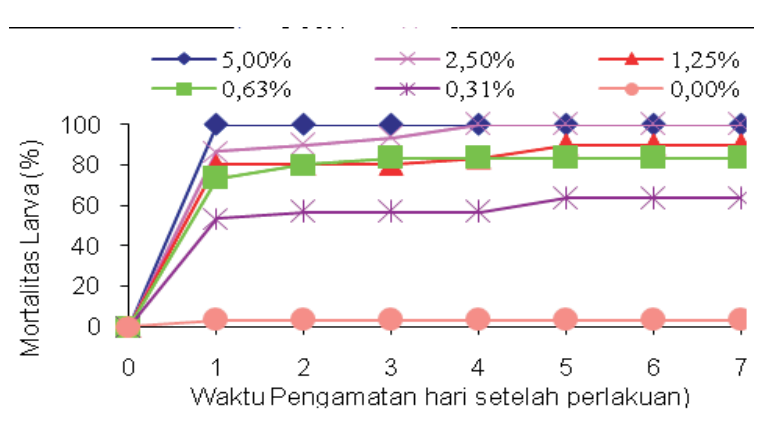

Gambar(Figure) 4. Mortalitas larva S. litura setelah perlakuan pada ekstrak metanol (ekstraksi maserasi bertingkat) dengan metode kontak (Mortality of larvae on methanol extract by soaking extraction with direct contact method) 


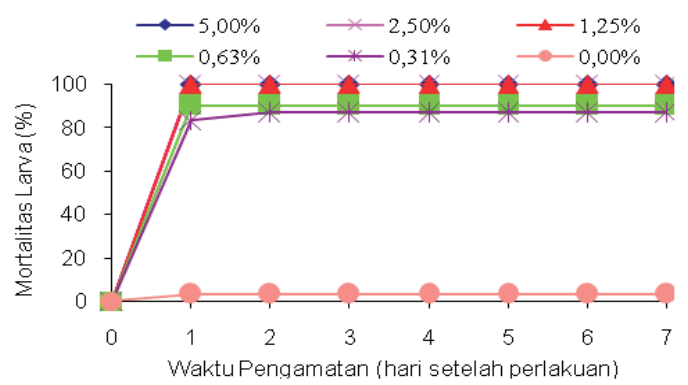

Gambar(Figure) 5. Mortalitas larva S. litura setelah perlakuan pada ekstrak etil asetat (ekstraksi maserasi bertingkat) dengan metode kontak (Mortality of larvae on ethyl acetate extract by soaking extraction with direct contact method)
Hasil analisis probit menunjukkan nilai lethal concentration $\left(\mathrm{LC}_{50}\right)$ ekstrak metanol dan n-heksan menunjukkan 1,5 kali dan 4 kali lebih tinggi dari nilai $\mathrm{LC}_{50}$ ekstrak etil asetat. Begitu juga nilai $\mathrm{LC}_{95}$ ekstrak etil asetat 1,5 kali lebih rendah daripada ekstrak metanol dan 8 kali lebih rendah daripada ekstrak heksan (Tabel 3). Hasil-hasil penelitian ini menunjukkan bahwa ekstrak etil asetat paling toksik atau paling aktif menyebabkan mortalitas larva S. litura instar ke tiga, dibandingkan ekstrak metanol dan ekstrak n-heksan. Oleh karena itu untuk uji selanjutnya, pengujian hanya dilakukan pada ekstrak etil asetat.

Tabel(Table) 3. Daya racun berbagai ekstrak daun N. atropurpurea terhadap larva S. litura pada hari ketujuh setelah perlakuan dengan metode kontak (Toxicity of $\mathrm{N}$. atropurpurea leaf extract against $\mathrm{S}$. litura larvae on seventh day after treament with direct contact method)

\begin{tabular}{|l|l|l|}
\hline Jenis Ekstrak (Extract kind) & $\mathrm{LC}_{50}($ sk. 95 \%) & $\mathrm{LC}_{95}(\mathrm{sk} .95 \%)$ \\
\hline Ekstrak Heksan & $0,84 \%(-)$ & $4,47 \%(-)$ \\
\hline Ekstrak Metanol & $0,34 \%$ (batas atas 0,90) & $\begin{array}{l}0,89 \%(\text { batas bawah 0,56-batas } \\
\text { atas 7,29) }\end{array}$ \\
\hline Ekstrak Etil asetat & $0,23 \%$ (batas atas 0,49) & $\begin{array}{l}0,59 \% \text { (batas bawah 0,38-batas } \\
\text { atas 2,35) }\end{array}$ \\
\hline
\end{tabular}

Keterangan (Remarks): SK = Selang Kepercayaan

\section{Uji Lanjut (Penentuan $\mathrm{LC}_{50}$ dan $\mathrm{Lc}_{95}$ )}

Berdasarkan hasil analisis probit dapat ditentukan kisaran konsentrasi ekstrak untuk uji selanjutnya, yaitu $0,007 \%$ (pada Gambar 6 dibulatkan menjadi $0,01 \%), 0,12 \%, 0,23 \%$, $0,38 \%$ dan $0,59 \%$ serta kontrol (tanpa ekstrak hanya menggunakan air). Hasil pengujian lanjut ekstrak etil asetat daun $N$. atropurpurea terhadap mortalitas larva $S$. litura melalui metode kontak menunjukkan pola yang sama dengan percobaan sebelumnya. Mortalitas larva sudah terlihat nyata pada hari pertama dan relatif konstan pada hari berikutnya hingga hari ke tujuh setelah perlakuan (Gambar 6). Hasil pengujian ini menunjukkan ekstrak etil asetat mempunyai daya racun yang tinggi terhadap larva $S$. litura, pada konsentrasi $0,59 \%$ dapat mematikan larva sebesar $92,22 \%$, pada konsentrasi $0,38 \%$ dan $0,23 \%$ masing-masing dapat mematikan larva sebesar $83,33 \%$ dan $70,00 \%$ dan pada konsentrasi yang lebih rendah $0,12 \%$ dan $0,007 \%$ masih dapat mematikan larva sebesar $44,44 \%$ dan $22,22 \%$, dengan kematian kontrol sebesar $6,67 \%$.

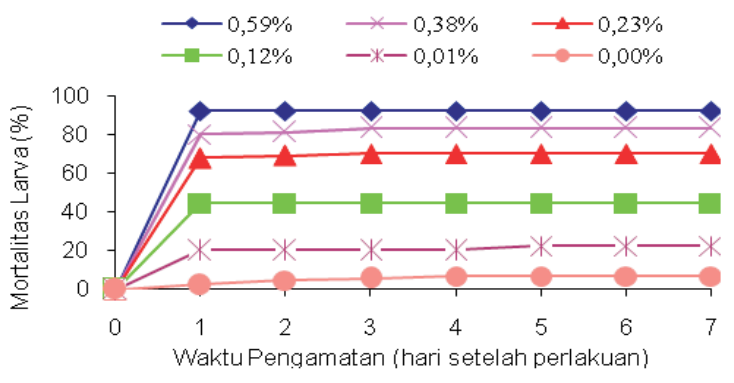

Gambar(Figure) 6. Mortalitas larva S. litura setelah perlakuan pada ekstrak etil asetat dengan metode kontak (Mortality of S. litura larvae on ethyl acetate with direct contactmethod)

Hasil analisis probit terhadap data jumlah mortalitas larva menunjukkan nilai $\mathrm{LC}_{50}$ ekstrak etil asetat daun $N$. atropurpurea adalah $0,18 \%$ dengan batas bawah $0,08 \%$ dan batas atas $0,29 \%$ dan $\mathrm{LC}_{95}$ sebesar $0,54 \%$ dengan batas bawah $0,39 \%$ dan batas atas $0,96 \%$.

Hasil analisis varians menunjukkan perlakuan konsentrasi berpengaruh nyata terhadap mortalitas larva S.litura. Hasil uji lanjut menunjukkan semua rentang konsentrasi uji 
berbeda nyata dengan kontrol (Gambar 7). Hasil uji korelasi menunjukkan ada hubungan yang sangat kuat antara konsentrasi terhadap mortalitas larva $S$. litura $(\mathrm{P}<0,01)$ yaitu tingkat mortalitas semakin tinggi seiring dengan meningkatnya konsentrasi.

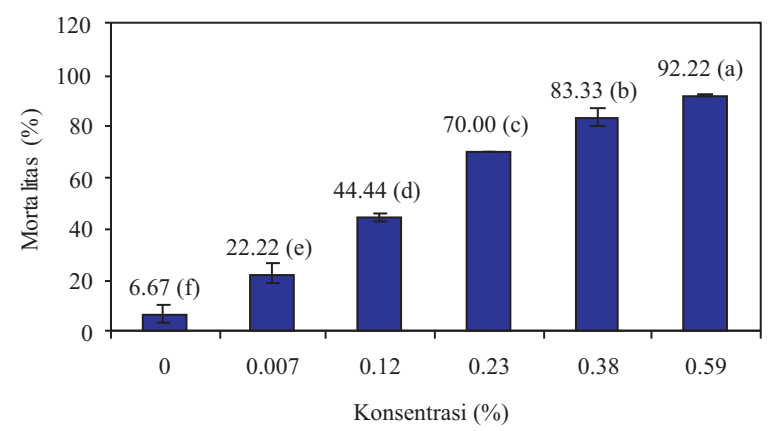

Gambar(Figure) 7. Rata-rata mortalitas larva $S$. litura \pm sd pada perlakuan ekstrak etil asetat dengan metode kontak dan uji Duncan (Angka-angka yang diikuti dengan huruf yang sama berarti tidak berbeda nyata pada taraf $\alpha=0,05$ ) (Average of S. litura larvae mortality \pm sd on ethyl acetate extract with direct contact method and Duncan test) (Figure followed with the same letters are not significantly different at $\alpha=0,05$ )

\section{B. Pembahasan}

\section{Cara Ekstraksi}

Berdasarkan hasil pengamatan menunjukkan toksisitas ekstrak yang diperoleh dengan cara maserasi bertingkat lebih tinggi dibandingkan ekstrak yang diperoleh dengan cara ekstraksi cair-cair, walaupun kadar ekstrak (rendemen) yang diperoleh dari ekstraksi caircair lebih tinggi. Hal ini menunjukkan cara ekstraksi mempengaruhi rendemen dan efektivitas ekstrak yang diperoleh. Seperti yang dikemukakan oleh Prijono (2003), selain cara penanganan bagian tumbuhan, cara ekstraksi dapat mempengaruhi efektivitas ekstrak yang diperoleh. Farrel (1990) juga mengemukakan dalam proses ekstraksi, rendemen yang dihasilkan akan dipengaruhi oleh jenis pelarut dan metode ekstraksi. Namun banyaknya rendemen yang dihasilkan bukan satu-satunya tolak ukur efektivitas ekstrak yang diperoleh, tetapi yang paling utama yaitu zat toksik yang terlarut (Tarmadi et al., 2007). Hasil penelitian ini mengindikasikan bahwa zat toksik yang terkandung dalam ekstrak yang diperoleh secara maserasi bertingkat lebih tinggi dibandingkan ekstrak yang diperoleh secara ekstraksi cair-cair.

Tingginya rendemen ekstrak yang dihasilkan dari pelarut metanol dibandingkan dari pelarut etil asetat dan n-heksan menunjukkan bahwa pelarut metanol adalah pelarut universal yang mampu melarutkan senyawa baik polar, semi polar bahkan non polar. Menurut Lenny (2006); Noor et al. (2006), pelarut metanol paling banyak digunakan untuk ekstraksi dan proses isolasi senyawa organik bahan alami karena dapat melarutkan seluruh golongan metabolit sekunder dan dapat menarik zat aktif yang terkandung di dalamnya sebanyak-banyaknya. Hal ini juga menunjukkan bahwa senyawa aktif yang terlarut dalam pelarut metanol tidak semuanya bersifat toksik terhadap $S$. litura .

\section{Toksisitas Ekstrak Daun N. atropurpurea}

Hasil pengujian terhadap ekstrak yang diperoleh secara maserasi bertingkat menunjukkan bahwa ketiga jenis ekstrak daun $N$. atropurpurea, yaitu ekstrak n-heksan, ekstrak etil asetat dan ekstrak metanol memiliki toksisitas yang kuat terhadap larva $S$. litura. Hal ini mengindikasikan ketiga ekstrak tersebut mengandung komponen senyawa aktif yang bersifat toksik terhadap larva $S$. litura. Diduga komponen senyawa aktif yang terdapat pada ketiga ekstrak relatif sama, tetapi jumlah (kandungan) bahan aktif yang bersifat toksik yang terekstraksi dalam masing-masing esktrak berbeda. Kemungkinan kandungan senyawa aktif yang terekstraksi dalam ekstrak etil asetat lebih tinggi, sehingga menyebabkan toksisitas ekstrak etil asetat lebih tinggi.

Hal ini sesuai dengan yang dikemukakan Harborne (1987), bahwa ekstraksi secara berkesinambungan dengan menggunakan pelarut secara berganti-ganti, mulai dengan pelarut non polar, kemudian semi polar dan polar jarang sekali mencapai pemisahan kandungan dengan sempurna dan senyawa yang sama mungkin saja terdapat tetapi dalam perbandingan yang berbeda dalam beberapa ekstrak atau fraksi. Hasil penelitian Naufalin (2005) menunjukkan bahwa komponen senyawa aktif yang terdeteksi dalam ekstrak n-heksan, ekstrak etanol dan ekstrak etil asetat bunga kecombrang ( $N$. speciosa) relatif sama, yaitu flavonoid, fenolik, steroid, terpenoid, alkaloid dan glikosida. Namun toksisitas ekstrak etil asetat lebih tinggi dalam menghambat mikroba dibandingkan ekstrak nheksan dan metanol, walaupun rendemennya lebih rendah. Begitu juga hasil penelitian 
Herawati (2006), hasil uji warna menunjukkan golongan metabolit sekunder yang terkandung didalam ekstrak metanol, esktrak diklorometan dan ekstrak etil asetat relatif sama, tetapi ekstrak etil asetat paling aktif sebagai biopestisida.

Pola perkembangan mortalitas larva $S$. litura pada ketiga ekstrak baik yang dihasilkan secara maserasi bertingkat maupun ekstraksi cair-cair menunjukkan pola yang sama. Pada semua rentang konsentrasi yang diuji, mortalitas larva sudah terlihat nyata pada hari pertama setelah perlakuan dan relatif konstan pada hari berikutnya hingga mendekati konstan pada hari ke lima setelah perlakuan. Pola perkembangan mortalitas ini mengindikasikan bahwa senyawa aktif yang terkandung dalam ekstrak daun $N$. atropurpurea memiliki cara kerja yang relatif cepat dalam menimbulkan mortalitas larva $S$. litura.

Hasil pengamatan memperlihatkan bahwa segera setelah perlakuan larva tidak bergerak, diduga larva mengalami kelumpuhan (efek knock down), walaupun kemudian ada diantaranya dapat bergerak kembali. Larva yang dapat bergerak kembali akan terus hidup hingga mencapai stadia pupa, sedangkan larva yang tidak bergerak lagi akan mengalami kematian dengan kondisi tubuh apabila disentuh lunak dan lemas serta warna tubuh berubah dari hijau kecoklatan menjadi coklat muda (Gambar 8). Di duga larva yang bisa bergerak kembali karena bisa menetralkan racun yang masuk ke dalam tubuhnya. Adanya proses kelumpuhan terlebih dahulu sebelum kematian serangga uji, diperkirakan senyawa aktif yang berasal dari ekstrak daun $N$. atropurpurea bekerja sebagai racun syaraf (Harahap, 1997). Hasil penelitian Enan (2001) menyatakan bahwa Periplaneta americana yang diperlakukan secara kontak dengan minyak atsiri (eugenol) yang bekerja sebagai racun syaraf menunjukkan gejala hiperaktif yang diikuti dengan hyperextention pada kaki dan abdomen, kemudian kelumpuhan atau tidak bergerak yang diikuti dengan kematian. Gejala ini sesuai dengan yang dikemukakan Tarumingkeng (1992), bahwa pada dosis median secara khas racun syaraf menimbulkan 4 tahap simptom yaitu : eksitasi (sering didahului dengan kegelisahan), konvulsi (kekejangan), paralisis (kelumpuhan) dan kematian.

Hasil uji korelasi menunjukkan semakin tinggi tingkat konsentrasi uji, mortalitas larva semakin tinggi, diduga karena semakin tinggi jumlah racun yang masuk dan terakumulasi ke dalam tubuh serangga melalui kutikula, sehingga senyawa aktif yang sampai keorgan sasaran juga tinggi, akibatnya tekanan terhadap aktivitas sistem syaraf menjadi lebih tinggi, yang berakibat paralisis dan kematian.

Pada seluruh gambar yang ada terlihat bahwa kematian yang nyata hanya terjadi 1 hari atau 24 jam setelah perlakuan. Hal ini memberi gambaran bahwa ekstrak daun $N$. atropurpurea ini kemungkinan hanya memiliki umur residu efektif 1 hari.

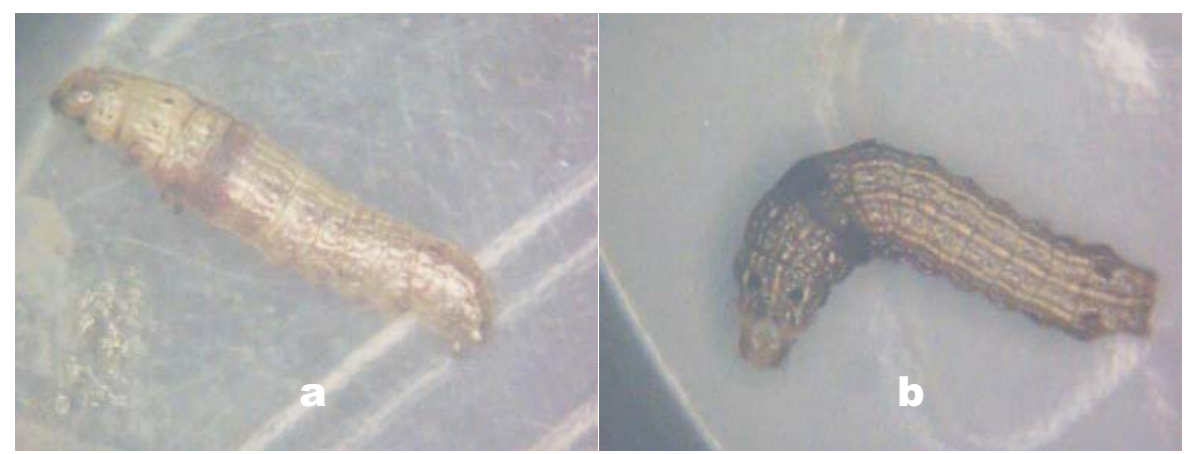

Gambar(Figure) 8. Larva yang mati (a) dan larva yang bertahan hidup (b) setelah aplikasi perlakuan ekstrak daun N. atropurourea (death larvae (a) and survive larvae (b) after N. atropurpurea leaf extract application) 


\section{KESIMPULAN DAN SARAN}

\section{A. Kesimpulan}

Ekstrak daun Nicolaia atropurpurea yang diaplikasikan dengan metode kontak bersifat toksik terhadap larva Spodaptera litura instar ketiga dengan nilai $\mathrm{LC}_{50}$ dan $\mathrm{LC}_{95}$ sebesar $0,18 \%$ dan $0,54 \%$. Semakin tinggi tingkat konsentrasi uji, mortalitas larva semakin tinggi ekstrak yang paling toksik dihasilkan dari ekstraksi maserasi bertingkat dengan menggunakan pelarut etil asetat.

\section{B. Saran}

Perlu penelitian lanjutan untuk mengembangkan potensi tumbuhan ini sebagai insektisida nabati, yaitu melakukan penelitian lanjutan terhadap aktivitas biologi lainnya dari ekstrak $N$. atropurpurea dan bagaimana pengaruhnya terhadap organisme non target (keamanannya). Penelitian untuk mengisolasi dan mengidentifikasi senyawa aktif daun $N$. atropurpurea yang bersifat toksik juga perlu dilakukan.

\section{DAFTAR PUSTAKA}

Dadang. 1999. Insect Regulatory and Active Substances of Indonesia Plants Particulary to the Diamond Back Moth Department of Bio Regulation Studies, Graduate School of Agriculture. Tokyo University of Agriculture. Disertasi.

Departemen Kesehatan. 2008. Daftar jenis-jenis tanaman obat. Riset Perguruan Tinggi/Unas/LIPI-PDII/Resep. http://www.smecda.com. Diakses 19/6/2010.

Doke, S. 2006. Uji toksisitas minyak atsiri kayu manis (Cinnamomum burmanii BL), serai wangi (Andropogon nardus L) dan jeruk purut (Citrus hystrix D.C.) terhadap jentik Aedes aegypti. Tesis Program Pascasarjana, Universitas Gadjah Mada, Yogyakarta. Tidak Dipublikasikan.

Enan, E. 2001. Insecticides activity of essential oils : octopaminergic sites of action. Comparative Biochemistry and Psysiology Part C.130: 325-337.

Escoubas, P., L. Lajide dan J. Mizutani. 1995. Termite antifeedant activity in
Aframomum melequeta. Phytochemistry, Vol.40, No.4: 1097-1099.

Farrel, K.T. 1990. Spices, condiments and seasonings. Second Edition AVI Pubs.Co.Inc. Westpat.Connecticut. http://books.google.co.id/books?id. Diakses 30/5/2009.

Harborne, J.B. 1987. Metode Fitokimia. Penuntun cara modern menganalisa tumbuhan. Terbitan Kedua. Penerbit ITB Bandung.

Herawati, Y. 2006. Uji aktivitas ekstrak daun mengkudu (Morinda citrifolia Linn) sebagai biopestisida melalui uji hayati lalat buah (Bactrocera dorsalis). Skripsi Jurusan Kimia. http://digilib.upi.edu. Diakses 30/5/2009.

Hilje, L. and G.A. Mora. 2006. Promissory botanical repellents/deterents for managing two key tropical insects pests, the whitefly Bemisia tabaci and mahogany shootborer Hypsipyla grandella. Rai and Carpinella (eds.) Naturally Occuring Bioactive Compounds. Elsevier B.V. All rights reserved.

Jaafar, F.M, C.P. Osman, N.H. Ismail dan K. Awang. 2007. Analysis of essential oils of leaves, stems, flower, and rhizomes of Etlingera elatior (Jack) R.M.Smith. Malaysian Journal of Analytical Science $11(1): 1-2$.

Kardinan, A. 1999. Pestisida Nabati, Ramuan dan Aplikasi. Penebar Swadaya. Jakarta.

Lenny, S. 2006. Isolasi dan Uji Bioaktivitas Kandungan Kimia Utama Puding Merah dengan Metode Uji Brine Shrimp. Karya Ilmiah, e-USU Repository, Universitas Sumatera Utara, medan.

Naufalin, R. 2005. Kajian sifat antimikroba ekstrak bunga kecombrang (Nicolaia speciosa Horan) terhadap berbagai mikroba patogen dan perusak pangan. Disertasi Sekolah Pascasarjana, Institut Pertanian Bogor (IPB). Tidak Dipublikasikan

Nugroho, W.B., B. Schwarz, V. Wray and P.Proksch. 1996. Insecticidal Constituents from Rhizome of Zingiber cassumunar and Kaempferia rotunda. Phytochemistry, Vol. 41, No.1: 129-132. 
Pandji, C., C. Grimm, V. Wray, L. Witte dan P. Proksch. 1993. Insecticidal constituents from four species of the zingiberaceae. Phytochemistry, Vol. 34, No.2: 415-419.

Prijono, D. 2003. Teknik Ekstraksi, Uji Hayati dan Aplikasi Senyawa Bioaktif Tumbuhan. Departemen Hama dan Penyakit Tumbuhan Fakultas Pertanian, IPB.

Robinson, T. 1995. Kandungan Organik Tumbuhan Tinggi. Penerbit ITB. Bandung

Schneider, C., F.I Bohnenstengel, B.W. Nugroho, V. Wray, K. Witte, P.D. Hung, L.C. Kiet dan P. Proksch. 2000. Insecticidal rocaglamide derivatives from Aglaia spectabilis (Meliaceae). Phytochemistry 54: 731-736.

Sumardi. 2008. Perlindungan Hutan Lanjut. Bahan Kuliah PSIK Program KhususKTB 602. Program Studi Ilmu KehutananFakultas Kehutanan Universitas Gadjah Mada.

Tampubolon, O.T., Suhatsyah, S. Sastrapradja. 1983. Penelitian pendahuluan kimia kecombrang (Nicolaia speciosa Horan). Risalah Simposium Penelitian Tumbuhan Obat III. Fakultas Farmasi, UGM. Yogyakarta.

Tarmadi, D., A.H. Prianto, I.Guswenrivo, T. Kartika dan S. Yusuf. 2007. Pengaruh ekstrak Bintaro (Carbera odollam Gaertn) dan Kecubung (Brugmansia candida Pers) terhadap rayap tanah Coptotermes sp. Jurnal Tropical Wood Science and Technology. Vol. 5, No.1:38-42.

Tarumingkeng, R.C. 1992. Insektisida: Sifat, mekanisme kerja, dan dampak penggunaannya. Jakarta; Ukrida.

Tawata, S., S. Taira, N. Kobamoto, M. Ishihara and S. Toyama. 1996. Synthesis and biological activities of dihydro-5,6dehydrokawain derivatives. Bioscience, Biotechnology and Biochemistry Vol.60. No:10: 1643-1645.

Yang, Y.C, I.K. Park, E.H. Kim, H.S. Lee and Y.J. Ahn. 2004. Larvicidal activity of medicinal plant extracts against Aedes aegypti, Ochlerotatus togoi, and Culex pipiens pallens (Diptera:Culicidae). J. Asia-Pasific Entomol. 7 (2): 227-232. 